\title{
Az ibuprofén helye a koronavírus-fertőzés kezelésében
}

\author{
Sütő Gábor dr. \\ Pécsi Tudományegyetem, Általános Orvostudományi Kar, Klinikai Központ, \\ II. Belgyógyászati Klinika, Nephrologiai és Diabetológiai Centrum, Pécs
}

\begin{abstract}
A koronavírus-fertőzés 2019 végén indult útjára, lassan a Föld teljes lakosságát elérő pandémiaként. Egy olyan kórokozóról van szó, amely ilyen nagy számú megbetegedést még nem okozott, ezért annak természetes lefolyásáról, a szövődmények kialakulásáról és a kezelési lehetőségekről még keveset tudunk. Ennek következtében a kezdetben megjelent információk nagyon felületesek voltak, a következtetések nemritkán tévútra vezették mind az orvosokat, mind a betegeket. Az adatok gyarapodásával azonban egyre több kérdésre kapunk választ. Erre a folyamatra az egyik legreprezentánsabb példa az ibuprofén története, amely kezdetben tiltott, később türt terápiás szer volt, de ma már támogatott kezelési lehetőség a koronavírus-fertőzésben.
\end{abstract}

Orv Hetil. 2020; 161(50): 2104-2106.

Kulcsszavak: SARS-CoV-2, kezelés, ibuprofén

\section{The role of ibuprofen in the treatment of coronavirus infection}

The coronavirus infection started in late 2019, as a pandemic slowly reaching the entire population of the earth. This pathogen has not yet caused such a large number of diseases, so little is known about its natural course, the development of complications, and treatment options. As a result, the information initially published was very superficial, and the conclusions often misled both physicians and patients. As the data grows, however, we get more and more questions answered. One of the most representative examples of this process is the history of ibuprofen, which was initially banned, thereafter tolerated, and is now a supported treatment option for coronavirus infection.

Keywords: SARS-CoV-2, treatment, ibuprofen

Sütő G. [The role of ibuprofen in the treatment of coronavirus infection]. Orv Hetil. 2020; 161(50): 2104-2106.

(Beérkezett: 2020. október 20.; elfogadva: 2020. november 2.)

\section{Rövidítések}

ACE2 = (angiotensin-converting enzyme 2) 2-es típusú angiotenzinkonvertáló enzim; ARB = angiotenzin-II-receptor-blokkoló; COVID-19 = (coronavirus disease 2019) koronavírusbetegség 2019; EMA = (European Medicines Agency) Európai Gyógyszerügynökség; SARS-CoV-2 = (severe acute respiratory syndrome coronavirus 2) súlyos akut légúti tünetegyüttest okozó koronavírus-2; WHO = (World Health Organization) Egészségügyi Világszervezet

$\mathrm{Az}$ új típusú koronavírus (SARS-CoV-2)-fertőzés 2019 második felében indult útjára, Magyarországon 2020. március 4-én diagnosztizálták az első, SARS-CoV-2-fertőzött beteget. Az eltelt közel egy évben a vírus körbeért az egész Földön. Habár a fertőzések nagy száma tünet- mentes, vagy enyhe megbetegedés után gyógyul, sokaknál súlyos szövődményeket hagy hátra, akár halált is okoz. Ismereteink sokat gyarapodtak a felfedezése óta, de még mindig nagyon sok minden tisztázatlan, beleértve a hatásos terápiát is. A súlyos szövődmények kezelésére számos protokoll jelent meg, amelyek kezdetben elméleti megfontolások alapján készültek, de mára egyre több vizsgálat folyik az antivirális szerek mellett a gyulladácsökkentő és immunmoduláns gyógyszerek hatásosságának felmérésére. A gyulladáscsökkentő szerek és ezeken belül az ibuprofén alkalmazása érdekes utat futott be: a kezdeti tiltást a tûrés kategóriája váltotta fel, és ma már alkalmazott kezelés akár a nemszteroid, akár a szteroid típusú gyulladáscsökkentők adása.

2020. március 14-én Olivier Véran francia egészségügyi miniszter, aki a civil életben neurológus, egy Twit- 
ter-üzenettel indította el azt a lavinát, amely a gyulladáscsökkentő szerek és ezek között is az ibuprofén kártékony hatását feltételezte a SARS-CoV-2-fertőzésben. Három nappal korábban megjelent egy levél a Lancet folyóiratban, amelyben a 2-es típusú angiotenzinkonvertáló enzim (ACE2) nagyobb mennyiségét feltételezi a renin-angiotenzin-aldoszteron gátló és az angiotenzinII-receptor-blokkoló (ARB-) kezelésben részesült cukorés hypertoniás betegeknél [1]. Ez a fokozott termelődés elősegítheti a súlyosabb SARS-CoV-2-fertőzés kialakulását. Habár a cikk az ibuprofénre vonatkozó negatív állítást nem tartalmaz, azt feltételezik, hogy az ACE2 expresszióját fokozza, és a vírus sejtekbe történő belépését segíti elő. Ugyanezt feltételezik az ACE- és ARB-gátlókról is. Ugyanebben a hónapban a British Medical Journalben már úgy jelent meg az információ Véran tweetje kapcsán, hogy a doktorok és a tudósok nem javasolják az ibuprofén alkalmazását a koronavírus-fertőzés kezelésében [2]. Az alkalmazás elleni egyértelmú ajánlást azonban nem tesznek, sőt a kortikoszteroidot és immunszuppresszort szedő betegeknek egyértelmüen a gyógyszerszedés folytatását javasolják. Egy rövid időn belül megjelent további közleményben kapcsolatot feltételeztek az elhúzódó légúti és a cardiovascularis szövődmények, valamint a nemszteroid gyulladáscsökkentő szerek között, de a bizonyítékokat még nem tartották elegendőnek terápiás következtetések levonására [3]. Ugyanekkor a WHO a tudományos bizonyítékok hiányában már egyértelmúen nem javasolta az ibuprofén szedésének felfüggesztését koronavírus-fertőzött betegeknél [4], de az első lépésben paracetamol adását tanácsolta. Ekkor a vélemény már abba az irányba mozdult el, hogy szakmai érvek esetén, az alkalmazási szabályok figyelembevételével, nemszteroid gyulladáscsökkentők is adhatók [5]. A brit gyógyszerhatóság (Medicines and Healthcare Products Regulatory Agency) is készített ajánlást [6]. E szerint az ibuprofén alkalmazható, de felírásakor figyelembe kell venni a hagyományos rizikófaktorokat, a cardiovascularis és gastrointestinalis kórelözményt, vesebetegség jelenlétét, és a lehető legrövidebb ideig, a legkisebb adagban kell alkalmazni.

Áprilisban az ACE-gátlók és az ibuprofén szerepét tovább árnyalták. A rendelkezésre álló adatok már nem támasztottak kételyt sem az ACE-gátlók, sem az ibuprofén alkalmazását illetően a SARS-CoV-2-infekcióban. Az ACE-gátlók esetében nem találtak káros hatást, sőt némi előnyt is felfedezni véltek $[7,8]$. A nemszteroid gyulladáscsökkentőket szintén nem tartották károsnak, javaslatként a minél kisebb adagban, minél rövidebb ideig tartó adást fogalmazták meg. A fejfájás kezelésének áttekintése kapcsán jutottak arra a következtetésre holland szerzők, hogy az ibuprofén kirekesztése a terápiából nem indokolt [9].

Júniusban a vélemény már az volt, hogy összességében nem bizonyított az ibuprofén diszkvalifikációjának szükségessége a SARS-CoV-2-infekció kezeléséből. Az addig felhasznált adatok és forrásaik nem tiszták, validitásuk megkérdőjelezhető, így a gyógyszerbiztonsággal kapcsolatban számos kérdés merült fel [10]. A következtetéseket erösen torzíthatta például, hogy az ibuprofént súlyosabb állapotú betegek kapták, akiknél a paracetamol nem hatott. Így az esetleges negatív kimenetel nem a gyógyszertől, hanem a beteg állapotától függött. Mindettől függetlenül figyelembe kell venni, hogy a nemszteroid gyulladáscsökkentók ronthatják a már fennálló magas vérnyomás vagy szívelégtelenség állapotát. Ekkor már elérhetők voltak nagyobb betegszámú megfigyelések adatai is. 45 éves medián életkorú, igazoltan COVID-19-fertőzésben szenvedő, 403 beteg kezelése során sem a halálozásban, sem a respirátorigényben nem volt különbség, akár ibuprofénnel, akár paracetamollal történő kezelést kaptak [11]. A paracetamollal kezeltek száma ebben a vizsgálatban kicsit magasabb volt, habár ennek klinikai jelentősége kérdéses, mivel ezek a betegek idősebbek voltak, így nem a kezelés, hanem az életkor lehet inkább a hatásmódosító tényező.

Júliusban az ausztrál gyermekgyógyászati ajánlás azt javasolta, hogy az addigi kezelési protokollokon nem javasolt változtatni, az addig alkalmazott kezelési módokat - beleértve a nemszteroid gyulladáscsökkentők alkalmazását - kell folytatni [12]. A nemszteroid gyulladáscsökkentők indikációjában az általános szempontok figyelembevételét hangsúlyozták, különös tekintettel a gastrointestinalis, a renalis és a cardiovascularis toxicitásra. Ebből a szempontból viszont az ibuprofén inkább előnyös, mint hátrányt jelentő kezelés.

Egy augusztus elején megjelent közleményben még nagyobb volt az óvatosság - hiszen tudományos erejü bizonyítékok hiányában, figyelmen kívül hagyva az ibuprofén alkalmazásának paramétereit (dózis, az alkalmazás időtartama, időpontja) nem lehet következtetést levonni a gyógyszer biztonságosságát illetően. Szükségesnek tartották kettős vak-, placebokontrollált, randomizált vizsgálatok elvégzését. In vitro kísérletek adatai alapján az is felmerült, hogy az ibuprofén még protektív is lehet, mert elósegíti a vírus sejtbe jutását előmozdító ACE2-receptor lehasadását a sejtmembránról, illetve lassítja a proinflammatorikus intracelluláris jelátvitelt [13].

Egy szeptemberi, 9236 föt felölelő dán vizsgálatban (átlagéletkor: 50 év, 58\% nő) 248 betegnek írtak fel nemszteroid gyulladáscsökkentő szert. Az összes beteg közül 535 hunyt el 30 napon belül. Ezen az időszakon belül sem a halálozás, sem egyéb adverz reakció nem kapcsolódott a nemszteroid gyulladáscsökkentők szedéséhez [14].

Hosszú utat futott be a SARS-CoV-2-fertőzés kezelése, pedig a vírus még csak alig egy éve tűnt fel. Egyre több információ gyưlik össze, amelyek lehetővé teszik tudományos igényü következtetések levonását mind a betegség kialakulását és lefolyását illetően, mind a rendelkezésre álló gyógyszerek alkalmazására vonatkozóan. Hosszabb távon eredménnyel kecsegtető preventív beavatkozások (védőoltás) és új gyógyszerek is elérhető közelségbe kerültek. Addig sincsen semmi okunk, hogy a 
COVID-19-betegeknél az eddig alkalmazott gyógyszeres kezelésen - beleértve a nemszteroid gyulladáscsökkentők alkalmazását - változtassunk. A megfelelő gyógyszer kiválasztásakor az általános szempontok figyelembevétele javasolt: a lehető legkisebb adagban és a legrövidebb ideig kapjanak a betegek ilyen gyógyszert, és fokozottan tekintetbe kell venni az adott szer mellékhatásprofilját. Az ibuprofén a szokásos adagolásban alkalmazva az Európai Gyógyszerügynökség (EMA) ajánlása [15] szerint előnyös cardiovascularis mellékhatásprofillal rendelkezik. Ebben a tekintetben az ibuprofén és a dexibuprofén [16] egyenértékü.

Anyagi támogatás: A közlemény megírása anyagi támogatásban nem részesül.

A cikk végleges változatát a szerző elolvasta és jóváhagyta.

Érdekeltségek: A szerzőnek nincsenek anyagi érdekeltségei.

\section{Irodalom}

[1] Fang L, Karakiulakis G, Roth M. Are patients with hypertension and diabetes mellitus at increased risk for COVID-19 infection? Lancet Respir Med. 2020; 8(4): e21. [Erratum: Lancet Respir Med. 2020; 8(6): e54.]

[2] Day M. Covid-19: ibuprofen should not be used for managing symptoms, say doctors and scientists. BMJ 2020; 368: m1086.

[3] Little P. Non-steroidal anti-inflammatory drugs and Covid-19. BMJ 2020; 368: $\mathrm{ml} 185$.

[4] Weikle B. WHO clarifies guidance on ibuprofen, says there's no evidence it can worsen COVID-19. Available from: https:// www.cbc.ca/news/health/ibuprofen-covid-19-novel-coronavirus-1.5501496 [accessed: June 20, 2020].

[5] Sodhi M, Etminan M. Safety of ibuprofen in patients with COVID-19: causal or confounded? Chest 2020; 158: 55-56.

[6] GOV.UK. Commission on Human Medicines (CHM) advice on ibuprofen and coronavirus (COVID-19). Available from: https://www.gov.uk/government/news/commission-on-hu- man-medicines-advice-on-ibuprofen-and-coronavirus-covid-19 [accessed: June 20, 2020].

[7] Zolk O, Hafner S, Schmidt CQ. COVID-19 pandemic and therapy with ibuprofen or renin-angiotensin system blockers: no need for interruptions or changes in ongoing chronic treatments. Naunyn Schmiedebergs Arch Pharmacol. 2020; 393: 11311135 .

[8] Kutti Sridharan G, Kotagiri R, Chandiramani VH, et al. COVID-19 and avoiding ibuprofen. How good is the evidence? Am J Ther. 2020; 27: e400-e402.

[9] MaassenVanDenBrink A, de Vries T, Danser AH. Headache medication and the COVID-19 pandemic. J Headache Pain 2020; $21: 38$.

[10] Moore N, Carleton B, Blin P, et al. Does ibuprofen worsen COVID-19? Drug Saf. 2020; 43: 611-461.

[11] Rinott E, Kozer E, Shapira Y, et al. Ibuprofen use and clinical outcomes in COVID-19 patients. Clin Microbiol Infect. 2020; 26: 1259.e5-1259.e7.

[12] Vosu J, Britton P, Howard-Jones A, et al. Is the risk of ibuprofen or other non-steroidal anti-inflammatory drugs increased in COVID-19? J Paediatr Child Health 2020; 56: 1645-1646.

[13] Smart L, Fawkes N, Goggin P, et al. A narrative review of the potential pharmacological influence and safety of ibuprofen on coronavirus disease 19 (COVID-19), ACE2, and the immune system: a dichotomy of expectation and reality. Inflammopharmacology 2020; 28: 1141-1152.

[14] Lund LC, Kristensen KB, Reilev M, et al. Adverse outcomes and mortality in users of non-steroidal anti-inflammatory drugs who tested positive for SARS-CoV-2: a Danish nationwide cohort study. PLoS Med. 2020; 17: el003308.

[15] European Medicnes Agency. Assessment report for non-steroidal anti-inflammatory drugs (NSAIDs) and cardiovascular risk. Available from: https://www.ema.europa.eu/en/documents/ referral/assessment-report-article-53-procedure-non-steroidalanti-inflammatory-drugs-nsaids-cardiovascular_en.pdf [accessed: June 20,2020]

[16] European Medicines Agency. Updated advice on use of highdose ibuprofen. Available from: http://www.ema.europa.eu/ docs/en_GB/document_library/Press_release/2015/04/ WC500185426.pdf [accessed: June 20, 2020].

(Sütő Gábor dr., Pécs, Pacsirta u. 1., 7624 e-mail: gabor.suto@immunologus.hu)

A cikk a Creative Commons Attribution 4.0 International License (https://creativecommons.org/licenses/by/4.0/) feltételei szerint publikált Open Access közlemény, melynek szellemében a cikk bármilyen médiumban szabadon felhasználható, megosztható és újraközölhetö, feltéve, hogy az eredeti szerző és a közlés helye, illetve a CC License linkje és az esetlegesen végrehajtott módositások feltüntetésre kerülnek. (SID_1) 